\title{
Pancreatic exocrine responses to secretin, 2-deoxyglucose, a meal, and ethanol after coeliac ganglionectomy in the conscious dog
}

\author{
C D JOHNSON, M-A DEVAUX, AND H SARLES
}

From INSERM U3I, Marseille, France

SUMMARY The effects of coeliac ganglionectomy on pancreatic exocrine responses to graded doses of secretin, intravenous 2-deoxyglucose $100 \mathrm{mg} / \mathrm{kg}$, ethanol $0.56 \mathrm{~g} / \mathrm{kg}$, and $1 \mathrm{~g} / \mathrm{kg}$, and to a meat meal were studied in conscious dogs (weight 11 to $27 \mathrm{~kg}$ ). Five animals underwent coeliac ganglionectomy and up to seven control animals were studied. Coeliac ganglionectomy increased four-fold the pancreatic fluid response to secretin. The early part of the fluid response to 2-deoxyglucose was reduced, but there was no effect on the protein response to 2-deoxyglucose. In controls, ethanol $0.56 \mathrm{~g} / \mathrm{kg}$ stimulated pancreatic secretion, to nearly double the basal level, but after coeliac ganglionectomy this dose of ethanol inhibited secretion to one third of basal values. There was no effect of coeliac ganglionectomy on pancreatic response to ethanol $1 \mathrm{~g} / \mathrm{kg}$. After coeliac ganglionectomy the early response to a meal was increased by $100 \%$ for fluid output and by $50 \%$ for protein secretion, but from 10 minutes to two hours after the meal there was no effect on pancreatic response. These data shed further light on the mode of action of ethanol on pancreatic secretion, and they indicate that therapeutic coeliac ganglia ablation in man is unlikely to be detrimental to physiological pancreatic secretion.

Pancreatic exocrine secretion is regulated by both neural and hormonal mechanisms. There is some evidence that the splanchnic nerves may be involved in this regulation. In the anaesthetised cat, electrical stimulation of the splanchnic nerves was found to increase amylase secretion, but to reduce the volume of pancreatic juice. This effect was in part independent of changes in blood flow.' In those experiments the changes in amylase secretion appeared to be mediated by cholinergic fibres. There are no published data on the effect of stimulation or section of the splanchnic nerves in the conscious dog, but a previous study from this laboratory showed that chronic irritation of the splanchnic nerves with

Address for correspondence: Mr C D Johnson, MChir. FRCS. Department of Surgery, F Level, Southampton General Hospital, Tremona Road, Southampton, UK.

Accepted for publication 4 April 1989 pumice powder led to a reduced fluid and bicarbonate response to secretin and a slight reduction in protein output in response to cholecystokinin (CCK). ${ }^{2}$

In the management of painful pancreatic cancer or chronic pancreatitis, the splanchnic nerves to the pancreas may be interrupted by surgical or percutaneous destruction of the coeliac plexus and ganglia. This manoeuvre will also destroy some vagal fibres which are distributed through the coeliac ganglia and plexus. ${ }^{3}$ The effects of ablation of the coeliac ganglia on pancreatic secretion in man have not been reported, but we have previously shown that coeliac ganglionectomy in the dog reduces the release of gastrin and of cholecystokinin in response to a meat meal. ${ }^{+}$

This paper investigates the effect of surgical excision of the coeliac ganglia (coeliac ganglionectomy $(\mathrm{CG})$ on pancreatic responses to a variety of stimuli. 


\section{Methods}

\section{DOGS}

Mongrel dogs weighing $11 \mathrm{~kg}$ to $27 \mathrm{~kg}$ were kept individually in an enclosed, windowless, air conditioned kennel with artificial lighting for 12 hours each day. They were prepared under general anaesthesia with gastric and duodenal Thomas cannulae for the study of pancreatic secretion. In five dogs coeliac ganglionectomy was performed through a midline laparotomy. The lesser sac was opened and the stomach was retracted upwards. The coeliac ganglia were identified lateral to the aorta at the level of the coeliac axis, and the ganglia and plexus of nerve fibres around the coeliac trunk and hepatic artery were removed. The presence of neural tissue in the resected material was confirmed histologically. This procedure was well tolerated. All animals recovered satisfactorily, and maintained normal gastrointestinal function.

After an interval of at least three weeks after surgical preparation, experiments were carried out once or twice a week and never on consecutive days. After an 18 hour fast with free access to water, the dogs were placed in Pavlov slings and the gastric and duodenal cannulae were opened. The stomach was emptied and the pancreatic duct was cannulated with a fine glass cannula for the collection of pure pancreatic juice. An intravenous cannula was placed in a leg vein for the infusion of $0.15 \mathrm{M} \mathrm{NaCl}$ in which were dissolved hormones and stimulants.

Secretin was given in doubling doses from $0 \cdot 125$ $\mathrm{CU} / \mathrm{kg} / \mathrm{h}$ to $2 \mathrm{CU} / \mathrm{kg} / \mathrm{h}$. The dose was increased every 30 minutes. Pancreatic secretion was collected continuously in 10 minute samples. Five controls and five (coeliac ganglionectomy) dogs were tested.

2-deoxyglucose (2DG) was given as an intravenous infusion of $100 \mathrm{mg} / \mathrm{kg}$ over 30 minutes, during a continuous infusion of secretin $0.5 \mathrm{CU} / \mathrm{kg} / \mathrm{h}$. The infusion of 2DG was started at least one hour after the secretin, when a stable plateau of secretion had developed. Pancreatic juice was collected continuously in 15 minute samples. Seven control and four coeliac ganglionectomy dogs were tested.

The effect of intravenous ethanol was studied at two different dose levels on two separate occasions. Ethanol was diluted in $0 \cdot 15 \mathrm{M} \mathrm{NaCl}$. Secretin $0 \cdot 5 \mathrm{CU} /$ $\mathrm{kg} / \mathrm{h}$ was given continuously throughout the experiment. After at least one hour of secretin, ethanol 0.56 $\mathrm{g} / \mathrm{kg}$ (four controls, five coeliac ganglionectomy) or $1 \mathrm{~g} / \mathrm{kg}$ (six controls, four coeliac ganglionectomy) was infused intravenously over 20 minutes. Pancreatic juice was collected continuously in 20 minute samples.

The response to a meal was studied under basal conditions in seven controls and four coeliac

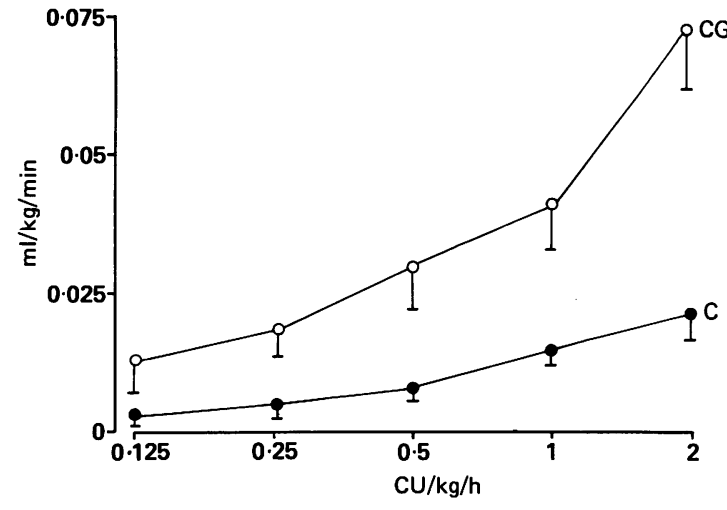

Fig. 1 Pancreatic fluid secretion in response to secretin $0 \cdot 125-2$ CU/ $/ \mathrm{kg} / \mathrm{h}$. Bars represent standard error of the mean (SEM). $C=$ controls $(n=5) ; C G=$ coeliac ganglionectomy $(n=5)$.

ganglionectomy animals. The meal consisted of $450 \mathrm{~g}$ tinned dog food containing $12 \%$ carbohydrate, $9 \%$ protein, $6 \%$ fat, $2 \%$ minerals, and $70 \%$ water. The meal was given after a basal period of 40 minutes, during which pancreatic juice was collected, measured and returned to the duodenum. All animals ate the meal within three minutes. Pancreatic juice was collected continuously in five minute samples for the first 20 minutes after starting the meal, then 20 minute samples thereafter. The volume of juice was measured, a small aliquot was retained for analysis and the juice was returned to the duodenum.

All samples of pancreatic juice were assayed for bicarbonate and protein concentrations. Bicarbonate output was found to closely reflect the volume of juice secreted, so only the data for volume are presented. Protein concentration in the pancreatic juice was measured after suitable dilution using a Gilson UM spectrophotometer at $280 \mathrm{~nm}$.

The dose response curves to secretin were analysed using the Eadie-Hofstee linear transformation (response $v$ response/dose) $)^{5}$ and linear regression analysis. The linear transformation enabled calculation of maximal response ( $\mathrm{R}$ max; corresponds to the Y-intercept) and the dose producing half maximal response (ED50; corresponds to the slope of the line). The responses to $2 \mathrm{DG}$, alcohol and the test meal were assessed using the Mann-Whitney $U$ test for comparison between groups and the Walsh test within groups.

To overcome inaccuracies related to the different weights of the dogs studied, results are expressed as output $/ \mathrm{kg} / \mathrm{min} .^{6}$ These outputs were compared directly, and also after summation of the rates of output for the whole test. Summated outputs were 


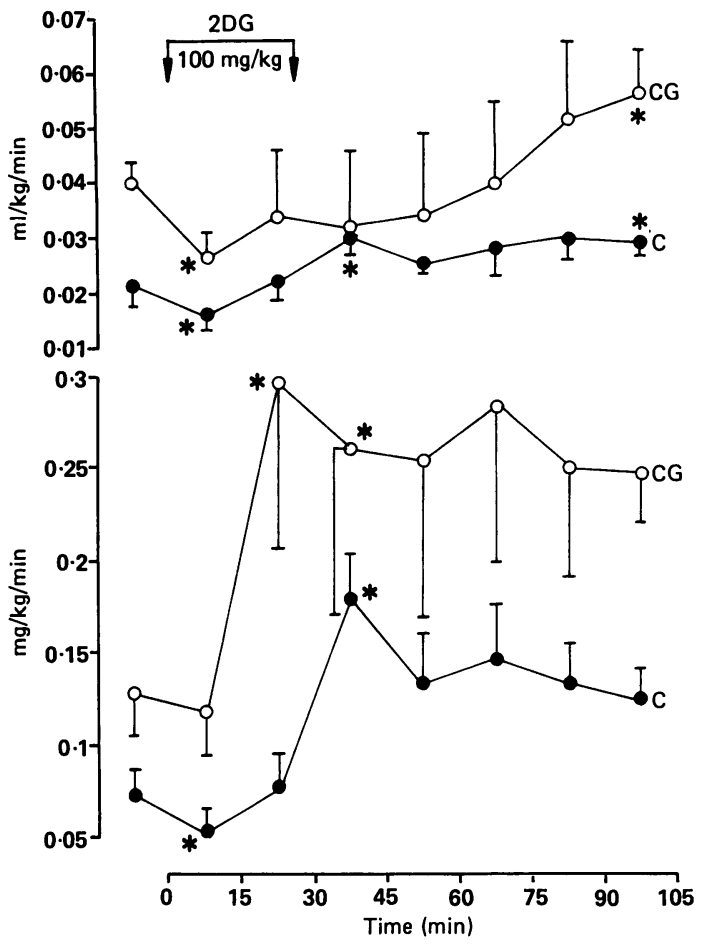

Fig. 2 Pancreatic responses to 2-deoxyglucose (2DG) during continuous infusion of secretion $0.5 \mathrm{CU} / \mathrm{kg} / \mathrm{h}$. Bars represent $S E M$. $P=$ plateau; $C=$ controls $(n=7) ; C G=$ coeliac ganglionectomy $(n=4)$. Significant differences from plateau of individual points shown by $\star$. Differences between the two groups are described in the text and the Table.

calculated using changes from basal values in the 2DG, ethanol and meal tests.

\section{Results}

\section{SECRETIN}

There was a steady progression of fluid secretion in response to secretin both in controls and after coeliac ganglionectomy (Fig. 1). Fluid output was increased in the coeliac ganglionectomy groups at all doses of secretin. Summated outputs during the test were significantly greater after coeliac ganglionectomy (Table). The linear regression of the Eadie-Hofstee transformation can be expressed as: controls: $\mathrm{y}=0.034-1.4 \mathrm{x}, \mathrm{r}=0.926$; coeliac ganglionectomy: $y=0.081-0.73 x, r=0.843$. The standard error of the regression coefficient was controls: 0.264; coeliac ganglionectomy: $0 \cdot 21$. $95 \%$ confidence limits for estimates of y (response) were controls: $0.006 \mathrm{ml} /$ $\mathrm{kg} / \mathrm{min}$; coeliac ganglionectomy: $0.026 \mathrm{ml} / \mathrm{kg} / \mathrm{min}$. Thus, after coeliac ganglionectomy, $\mathrm{Rmax}$ was increased and ED50 was reduced.
Table Summated pancreatic outputs after various stimuli in controls and after coeliac ganglionectomy. Secretin responses represent the sum of rates of total output; other responses are the sums of changes from basal outputs

\begin{tabular}{|c|c|c|c|c|}
\hline & $\begin{array}{l}\text { Controls } \\
\text { output }\end{array}$ & $\begin{array}{l}\text { Coeliac } \\
\text { ganglionectomy } \\
\text { output }\end{array}$ & $U$ & $P$ \\
\hline \multicolumn{5}{|c|}{ Fluid response $\left(\sum \mathrm{ml} / \mathrm{kg} / \mathrm{min}\right)$} \\
\hline Secretin & $0.059(0.01)$ & $0.261(0.091)$ & 0 & $0.0(0) 4$ \\
\hline $2 \mathrm{DG}$ & $+(0 \cdot(1) 36(0 \cdot() 28)$ & $-0.01(0.07)$ & 9 & 0.2 \\
\hline Ethanol $0.56 \mathrm{~g} / \mathrm{kg}$ & $+0 \cdot(041(0 \cdot 008)$ & $-0 \cdot 01(0 \cdot 056)$ & 2 & $0 \cdot(032$ \\
\hline Ethanol $1 \mathrm{~g} / \mathrm{kg}$ & $-0.017(0 \cdot 011)$ & $-0 \cdot 011(0 \cdot 012)$ & 9 & $0) \cdot 3$ \\
\hline Meal & $+0 \cdot(047(0 \cdot 008)$ & $+(0 \cdot(053(0 \cdot 003)$ & 11 & $0 \cdot 3$ \\
\hline \multicolumn{5}{|c|}{ Protein response $\left(\sum \mathrm{mg} / \mathrm{kg} / \mathrm{min}\right)$} \\
\hline 2DG & $+0 \cdot 34(0 \cdot 1)$ & $+0.55(0.25)$ & 10 & $0 \cdot 26$ \\
\hline Ethanol $0.56 \mathrm{~g} / \mathrm{kg}$ & $+(0 \cdot 26(0 \cdot 08)$ & $-0.52(0.26)$ & 1 & $0 \cdot 016$ \\
\hline Ethanol $1 \mathrm{~g} / \mathrm{kg}$ & $+0 \cdot(046(0 \cdot 074)$ & $+0 \cdot(026(0) \cdot 20)$ & 6 & $0 \cdot 13$ \\
\hline Meal & $+1 \cdot 20(0 \cdot 23)$ & $+1.28(0 \cdot 19)$ & 13 & $0 \cdot 5$ \\
\hline
\end{tabular}

Values are mean (and standard error of mean: SEM).

Increased pancreatic secretion in response to intravenous secretin was also found after coeliac ganglionectomy in the $2 \mathrm{DG}$ and ethanol experiments (Figs 2,3 ; increases in plateau fluid output $\mathrm{p}=0.003$ and 0.032 ; increases in plateau protein output, $\mathrm{p}=0.082$ and 0.009 respectively).

$2 \mathrm{DG}$

During the infusion of $2 \mathrm{DG}$ in controls there was a significant reduction in fluid and protein secretion $(p<0 \cdot 01$, Fig. 2). The reduction in fluid secretion persisted after coeliac ganglionectomy $(p=0.062)$ but the inhibition of protein secretion was abolished by cocliac ganglionectomy. The output of fluid after 2DG, expressed as the sum of the changes from plateau was not significantly different between controls and coeliac ganglionectomy (Table) but the significant rise in fluid secretion scen between 30 and 45 minutes in controls $(p=0 \cdot 043)$ was apparently abolished by coeliac ganglionectomy. In this group, pancreatic fluid output did not rise above the plateau level until 60-75 minutes after the start of the 2DG infusion.

The shape of the protein response curve to 2DG was not affected by coeliac ganglionectomy. The total output of protein in response to 2DG was greater after coeliac ganglionectomy but there was no difference in the summated changes from basal (Table).

ETHANOL

The effect of ethanol $0.56 \mathrm{~g} / \mathrm{kg}$ was different in the two groups (Fig. 3). In controls there was a consistent stimulation above plateau values of both fluid and protein output during and after the infusion of 

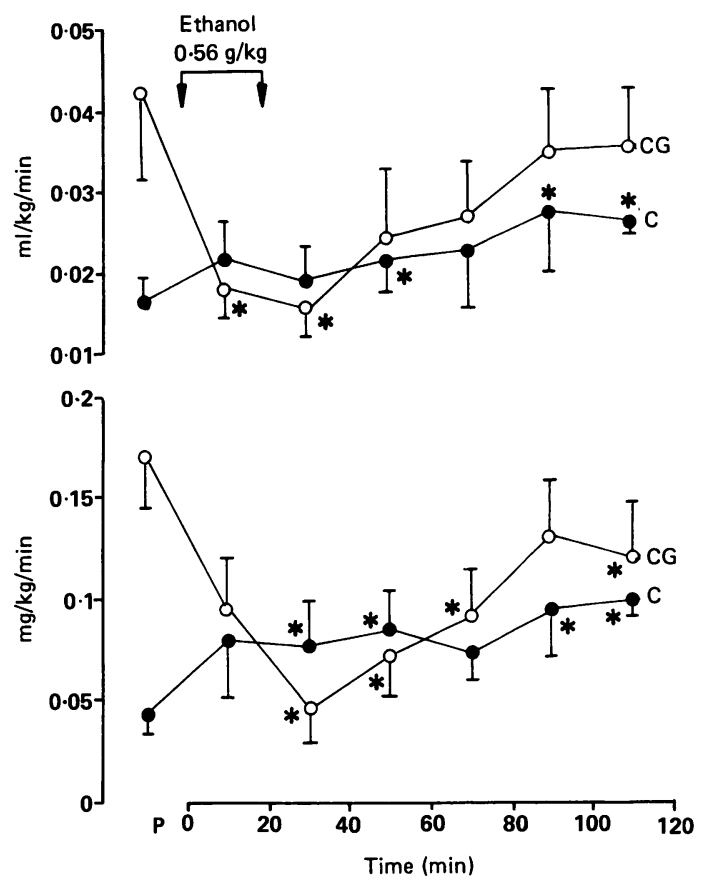

Fig. 3 Pancreatic responses to ethanol $0.56 \mathrm{~g} / \mathrm{kg}$ during continuous infusion of secretin $0.5 \mathrm{CU} / \mathrm{kg} / \mathrm{h}$. Symbols as in Figure 2. $C: n=4$; $C G: n=5$.

ethanol. In contrast, after cocliac ganglionectomy there was a higher plateau and secretion was inhibited by ethanol. The changes from plateau in the coeliac ganglionectomy group were significantly different from those seen in controls (Table).

There was no difference in response to ethanol $1 \mathrm{~g} / \mathrm{kg}$ in controls and after coeliac ganglionectomy. There was a reduction in output of fluid and protein during and after the infusion which was significant in both groups at 20-40 minutes (Fig. 4). Overall changes from plateau in response to ethanol $1 \mathrm{~g} / \mathrm{kg}$ were not significant, and there was no difference between controls and coeliac ganglionectomy (Table).

\section{TEST MEAL}

In contrast with secretin stimulated secretion, there was no significant difference after coeliac ganglionectomy in basal fluid or protein outputs (Fig. 5). Total fluid and protein responses to the meal were also similar in controls and the coeliac ganglionectomy group. The higher secretion seen after coeliac ganglionectomy during the first 10 minutes after feeding, however, reached statistical significance (fluid 0-5 min, $\mathrm{p}=0.019,6-10 \mathrm{~min}, \mathrm{p}=0.057$; protein 0-5 min and 6-10 min, $\mathrm{p}=0 \cdot 057$ ) (Fig. 5).
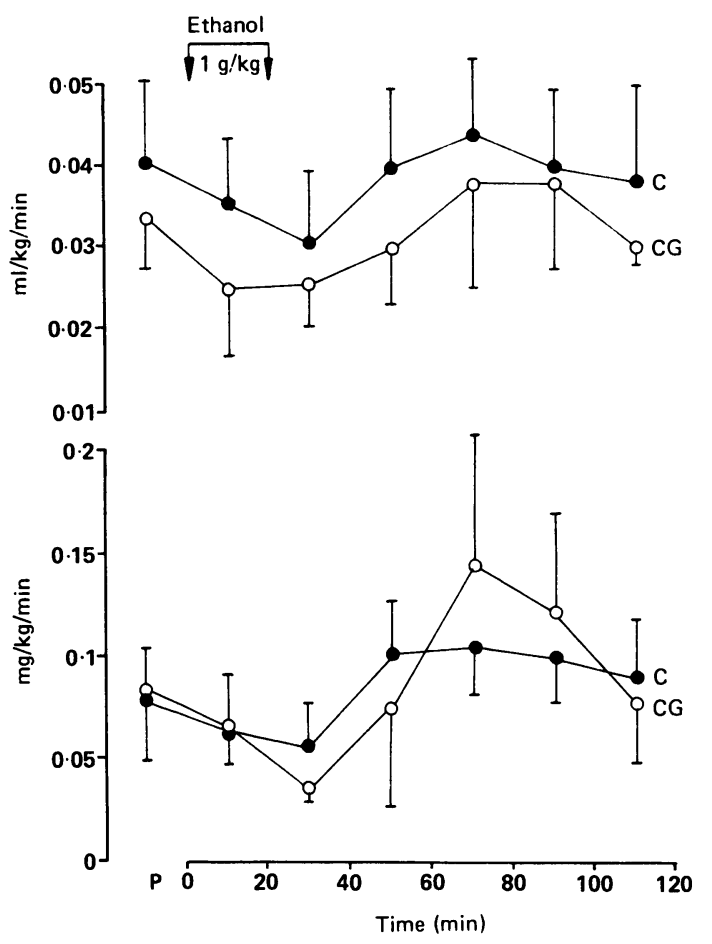

Fig. 4 Pancreatic responses to ethanol $1 \mathrm{~g} / \mathrm{kg}$ during continuous infusion of secretin $0.5 \mathrm{CU} / \mathrm{kg} / \mathrm{h}$. Symbols as in Figure 2. $C: n=6 ; C(j: n=4$.

\section{Discussion}

These experiments have shown that coeliac ganglionectomy increases pancreatic secretion in response to intravenous secretin, while reducing some of the effects of 2DG. There is a more complex interaction with the effects of ethanol but the only demonstrable effect on the physiological response to a meat meal was a small increase in the early phase of the response.

The increased pancreatic response to secretin is well demonstrated both in the dose response curve (Fig. 1) and in the increased fluid secretion seen in the prestimulation plateau in Figures 2 and 3. This increased sensitivity could be accounted for by the destruction of splanchnic inhibitory fibres passing through the coeliac ganglia and plexus as proposed by Barlow et al.' Those authors found that the changes in response after splanchnicectomy could not be explained solely on the basis of changes in blood flow. The increased response to secretin is also consistent with earlier findings from our laboratory' that chronic splanchnic nerve irritation can reduce fluid output in response to secretin. 

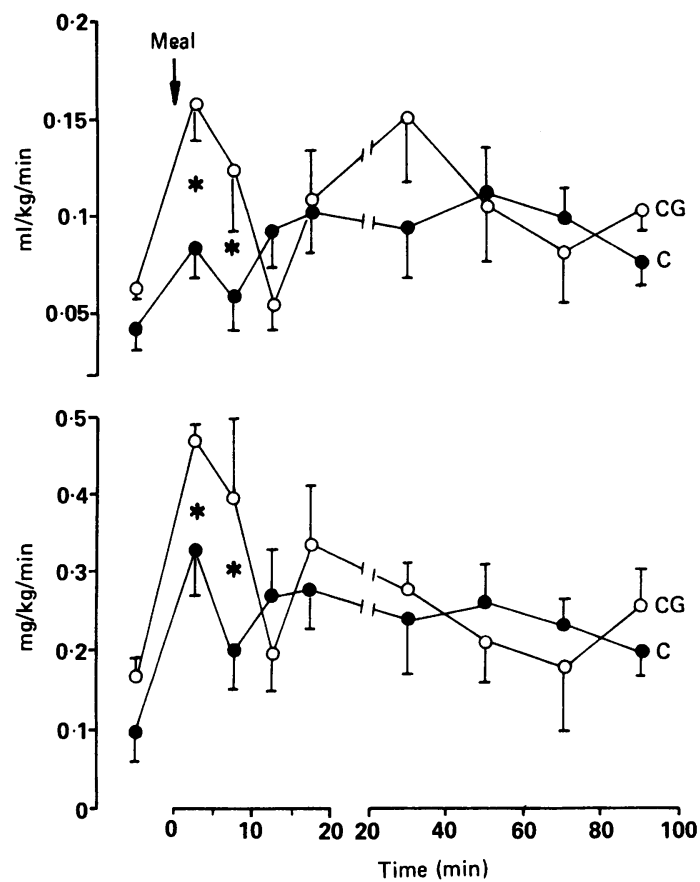

Fig. 5 Pancreatic responses to a $450 \mathrm{~g}$ meat meal. Symbols as in Figure 2, plateau signifies basal conditions. $C: n=7$; $C G: n=4$. All points were significantly greater than basal values except $C: 6-10 \mathrm{~min}$ and $C G: 11-15 \mathrm{~min}$. Significant differences between the groups shown by *.

2DG stimulates pancreatic secretion in a way analogous to insulin hypoglycaemia. Intracellular glycopenia results from competitive inhibition of glucose transport, and stimulates hypothalamic glucoreceptors. This initiates efferent activity to the gut and pancreas, largely but not entirely mediated by the vagus. ${ }^{7-4}$ In contrast with the increased sensitivity to secretin, the fluid response to 2DG was reduced after coeliac ganglionectomy when compared with the control response (Fig. 2). We have previously reported" " the stimulation of fluid output immediately after the infusion of 2DG. This stimulation was abolished by coeliac ganglionectomy. Although one must be cautious in the interpretation of significant differences at single points on the graph, '" we have found this effect in three series of dogs. The abolition of this peak by coeliac ganglionectomy suggests that it is mediated by fibres passing through the coeliac ganglia. This effect of coeliac ganglionectomy is similar to the effect of chronic ethanol administration."'

Coeliac ganglionectomy removes some vagal fibres which traverse the ganglia, ${ }^{3}$ so it is not possible to say whether the change in fluid response after coeliac

ganglionectomy is the result of the interruption of vagal pathways or the splanchnic efferents.

The effects of intravenous ethanol on pancreatic secretion are complex. Noel-Jorand and Sarles ${ }^{1:}$ showed that low doses of ethanol $(0.56 \mathrm{~g} / \mathrm{kg})$ stimulate pancreatic fluid and protein secretion. This effect was inhibited by atropine, but only the stimulation of protein secretion was blocked by pentolinium, implying that the effect on fluid secretion might be a direct action of ethanol on either the duct cells or intrapancreatic neurones. Higher doses of ethanol inhibit pancreatic fluid and protein secretion. This inhibition is vagally mediated by cholinergic fibres. ${ }^{1215}$

In contrast, after coeliac ganglionectomy ethanol $0.56 \mathrm{~g} / \mathrm{kg}$ reduced fluid and protein output. The stimulatory effect of low dose ethanol appears to be dependent on the splanchnic nerves of the coeliac ganglia. Coeliac ganglionectomy abolishes this effect, unmasking the inhibitory effect, which normally predominates only at higher doses of ethanol.

After ethanol $1 \mathrm{~g} / \mathrm{kg}$, the inhibitory effect is already starting to balance the stimulatory effect and no change in response was observed after coeliac ganglionectomy. Therefore, the stimulatory effect, but not the inhibitory effect of intravenous ethanol appears to require intact cocliac ganglia.

Despite these changes in the pancreatic responses to hormonal and various neurally mediated stimuli, there was only a small change in the early response to a meal. The increased output during the first 10 minutes after a meal is consistent with the interruption by coeliac ganglionectomy of inhibitory fibres. Alternatively, the increased response could be related to possible differences in the stimulus to the pancreas. Although outputs have been corrected for body weight, each animal was given a standard meal weighing $450 \mathrm{~g}$. It is possible that the response related to body weight may be greater in smaller animals given the same quantity of food.

The lack of any reduction after coeliac ganglionectomy of pancreatic responses to a meal and evidence that coeliac ganglionectomy removes some inhibitory fibres is encouraging for those who excise or destroy the coeliac ganglia and plexus by surgery or injections in the treatment of painful pancreatic diseases. In chronic pancreatitis there may be exocrine insufficiency, and so it is reassuring that we have found no evidence that coeliac ganglionectomy reduces pancreatic response to food.

Our data suggest that there may be inhibitory fibres for pancreatic fluid secretion which traverse the cocliac ganglia or plexus. Some vagal secretory fibres, mediating the response to $2 \mathrm{DG}$, may also traverse the ganglia or plexus. The action of ethanol 
and the anatomical distribution of the nerves mediating its action still appear complex. Stimulation of pancreatic secretion by low dose ethanol depends on the coeliac ganglia. It is possible that this effect might be caused by blockade of inhibitory fibres by ethanol.

In conclusion, we have found that coeliac ganglionectomy in the dog increases pancreatic fluid secretion in response to secretin, but reduces the stimulatory effect of 2DG and low dose ethanol. There was a small increase in the early response to a meal, but no difference in the total response over two hours. These results indicate that the coeliac ganglia play a minor role in the regulation of pancreatic secretion, and have a largely inhibitory effect. It also seems that destruction of the coeliac ganglia in man will have no deleterious effect on pancreatic secretion.

We are grateful to Professor A A Harper for helpful comments on the manuscript and to Dr R Choux who performed the histological examinations. CDJ was in receipt of an MRC/Inserm French Exchange Travelling Fellowship. This work was presented in part at the Pancreatic Society of Great Britain and Ireland, November 1987.

\section{References}

1 Barlow TE, Greenwell JR, Harper AA, Scratcherd T. The influence of the splanchnic nerves on the external secretion, blood flow and electrical conductance of the cat pancreas. J Physiol 1974; 236: 421-33.

2 Bicha-Costello H, Mendes de Oliveira JP. Devaux MA. Lechene de la Porte P. Verine HJ. Sarles JC. Effects of chronic irritation of splanchnic nerves on pancreatic juice secretion in dogs. Acta Med Port 1984; 5: 165-70.

3 Tiscornia OM, Martinez JL, Sarles H. Some aspects of human and canine macroscopic pancreas innervation. Am J Gastroenterol 1976; 66: 353-61.
4 Johnson CD, Chayvialle JA, Devaux MA, Sarles H. Neural pathways for the release of gastrin, cholecystokinin and pancreatic polypeptide after a meal in dogs. Dig Dis Sci 1986; 31: 1361-9.

5 Dowd JE, Riggs DS. A comparison of estimates of Michaelis-Menten kinetic constants from various linear transformations. J Biol Chem 1965; 240: 863-9.

6 Robles-Diaz G, Devaux MA, Johnson CD, Adrich Z, Sarles $H$. Physiological conditions for the study of basal and meal stimulated exocrine pancreatic secretion in the dog. Absence of fecdback inhibition of basalsecretion. Can J Physiol Pharmacol 1982; 60: 1287-95.

7 Wick AN, Drury DR, Nakada HI, Wolfe HB. Localisation of the primary metabolic block produced by 2Deoxyglucose. J Biol Chem 1957; 224: 963-9.

8 Kadekaro M, Timo-Iaria C, Valle LER, Velha LPE. Site of action of 2-deoxy-D-glucose mediating gastric secretion in the cat. J Physiol 1972; 221: 1-13.

9 Debas HT. Konturek SJ, Grossman MI. Effect of extragastric and truncal vagotomy on pancreatic secretion in the dog. Am J Physiol 1975; 228: 1172-7.

10) Schmidt DN, Johnson CD. Devaux MA. Sarles H. Pancreatic responses to 2-deoxyglucose; effect of chronic cthanol fecding. Eur J Clin Invest 1984; 14: $111-5$.

11 Sarles H, Johnson CD, Noel-Jorand MC, Devaux MA, Schmidt D. Effect of environmental factors on pancreatic response to cthanol and 2-deoxyglucose in the dog. Dig Dis Sci 1983; 28: 879-88.

12 Elashoff JD. Down with multiple t-tests! Gastroenterology 1981; 80: 615-9.

13 Noel-Jorand MC, Sarles H. Simultaneous mechanisms on exocrine pancreatic secretion initiated by alcohol in the conscious dog. Dig Dis Sci 1983; 28: 879-88.

14 Tiscornia OM, Gullo L, Sarles H. The inhibition of canine pancreatic secretion by intravenous ethanol. Digestion 1973; 9: 231-40.

15 Tiscornia OM, Hage G, Palasciano G, Brasca A, Devaux MA, Sarles H. The effects of pentolinium and vagotomy on the inhibition of canine exocrine pancreatic secretion by intravenous ethanol. Biomedicine 1973; 18: 159-63. 